\title{
COMPARATIVE STUDIES BETWEEN RESIDUES OF NORFLOXACIN AND CIPROFLOXACIN IN BROILER CHICKENS WITH SPECIAL REFERENCE TO THEIR WITHDRAWAL TIME
}

\author{
El-Sheikh, W.M. A. and Elkahky, M.A.A
}

Dept of Pharmacology, Animal Health Research Institute, Tanta professional lab.

\begin{abstract}
A single oral dose of norfloxacin $(10 \mathrm{mg} / \mathrm{kg}$ b.w.) and ciprofloxacin $(5 \mathrm{mg} / \mathrm{kg}$ b.w.) was administered for 30 broiler chickens for studying the comparative pharmacokinetic and pharmacodynamic data as well as residues in poultry tissues. The concentrations of two drugs in serum samples and its residues in tissues were assayed using HPLC with fluorescence detection.
\end{abstract}

Results showed rapid absorption for two drugs reaching to maximum serum concentrations $(1.39$ and $4.46 \mu \mathrm{g} / \mathrm{ml})$ after 2 and $0.67 \mathrm{~h}$. The plasma levels were maintained above MIC90 recorded for major poultry pathogenic Gram-negative and Gram-positive bacteria for 10 and $24 \mathrm{~h}$ with norfloxacin and ciprofloxacin respectively. The study illustrated that the administered dose for two drugs were adequate for $24 \mathrm{~h}$ for controlling avian diseases caused by bacteria sensitive to these drugs. Seven and five days are enough as withdrawal periods for norfloxacin and ciprofloxacin respectively to decrease its concentrations blow the MRL authorized for these drugs . 


\section{INTRODUCTION}

Fluoroquinolones are important antibacterial agents because of its broad antibacterial activity in veterinary practice (Neer, 1988), that includes most of Gram-negative and part of Gram-positive pathogenic bacteria (Ito, et al, 1980) as well as Mycoplasma spp. and Chlamydia spp.(Proctor et al, 1978 and Shah, 1990). Otherwise, its $2^{\text {nd }}$ generation as norfloxacin and ciprofloxacin are used extensively both as oral and injectable formulations for many domestic species due to its good bioavailability and good to excellent tissue distribution, as well as its high activity against aerobic and facultative anaerobic Gram-negative bacilli (Papich, 1998). They exert their bactericidal effect against Gramnegative bacteria in a concentration-dependent manner and show a moderate post-antibiotic effect (Neu et al., 1987).

The rational use of norfloxacin and ciprofloxacin for the treatment of common infections in poultry requires detailed information on its pharmacokinetic and pharmacodynamic properties in birds to establish the orally administered dose necessary for maintaining bactericidal drug concentrations in the body. These properties, when combined with microbiological data, provide the right tools needed for targeting its dosage to birds on the basis of pharmacokinetics and the susceptibilities of the bacterial pathogens (Sárközy et al, 2004).

For this, the present study was undertaken to obtain comparative pharmacokinetic data after a single oral administration of norfloxacin and ciprofloxacin; commercial products, in broiler chickens, as well as its residues in different tissues. 


\section{MATERIALS AND METHODS}

\section{A-Drugs:-}

1- Norfloxacin:(Mycomas 20\% oral liquid,UNIVET Ireland).A synthetic antibacterial $2^{\text {nd }}$ generation fluoroquinolone (Ryoji et al., 2006), rapidly bactericidal, active against organisms that may be resistant to other antibacterials such as sulphonamides, B-lactam, tetracyclines, aminoglycosides and macrolides (Neu and Labthavikul, 1982, and Crumplin et al.,1984) and have great potential for treating common infections such as mycoplasmosis, colibacillosis and pasteurellosis in chickens, turkeys and geese (Norrby and Jonsson, 1983; Prescott and Baggot, 1993 and Keck and Borne, 1995).

2- Ciprofloxacin: (Atociprim 20\% oral powder, Atcopharma, Egypt) A synthetic antibacterial $2^{\text {nd }}$ generation fluoroquinolone (Ryoji et al., 2006), highly effective against both Gram-negative and Gram-positive bacteria including Pseudomonas aeruginosa (Hackbarth, et al., 1986; Neu, 1987; Campoli-Richards, et al.,1988; Demoleas and Davies, 1988; Lefevre, et al., 1988 and Neer, 1988) and treat gonorrhoea, bacterial gastroentritis, skin and soft tissue infections, complicated and uncomplicated urinary tract infections caused by Gram-negative organisms in poultry (Amjad et al, 2005).

\section{B- Animals:-}

Sixty healthy Hubbard broiler chickens 35 days of age $(1.2-1.5 \mathrm{~kg}$ body wt), were divided into 2 groups, each thirty marked and housed in separate partition. They acclimatized for one week before the beginning of the experiment, fed on a balanced ration free from any drug or growth promoter and water was available ad libitum. A single oral dose of norfloxacin $(10 \mathrm{mg} / \mathrm{kg}$ b.w for group 1) or ciprofloxacin $(5 \mathrm{mg} / \mathrm{kg}$ b.w for group 2) was given directly into the crop for each bird after food holding for $12 \mathrm{~h}$ before and $6 \mathrm{~h}$ after drug administration. 


\section{C- Sampling:}

One $\mathrm{ml}$ of blood was collected from five birds of each group, in heparinized tubes from the contralateral wing vein through a fine plastic intravenous catheter. The samples were taken prior and at 10, 20, 30, 40 min, 1, 2, 3, 4, 6, 8, 12, and 24h after drug administration. Plasma was separated by centrifuge at $3000 \mathrm{~g}$ for $5 \mathrm{~min}$ and stored at $-20{ }^{\circ} \mathrm{C}$ until assayed. Five birds were slaughtered daily from each group, at 5, 6, 7 and 8 days for group 1 and at 4, 5, 6 and 7 days for group 2, samples from muscle, liver and kidney were taken and extracted according methods described by (Amjad et al, 2005) for detection of drug residues. Concentration of two drugs in plasma and tissue extracts were determined by HPLC with fluorescence detection with quantitation limits of $0.02 \mu \mathrm{g} / \mathrm{ml}$ according methods described by Laczay et al, (1998) for norfloxacin and Horie et al, (1994) for ciprofloxacin.

The HPLC system consisted of 1525 binary HPLC pump (Waters, Version Number Control Firmware 1.06. CPU Firmware1.3, USA), 717 plus autosampler (Waters, Version Number 3.1, USA), degasserin-Line2 Cham AF (Waters, Version Number 1.04, USA), 2475 multi $\lambda$ fluorescence detector (Waters, Version Number 1.00, USA) and software Breeze (Waters Breeze ${ }^{\mathrm{TM}}$ HPLC system software).

\section{D- Standard materials:}

From Dr. Ehrenstorfer GmbH D-86199 Augsburg Germany. Ciprofloxacin hydrochloride (Reference Standard) Cat. No. C 11668500 MW 367.64 CAS 86393 32-0 Norfloxacin (Reference Standard) Cat. No. C 15648000 MW 319.3. CAS 70458-96-7.

\section{E- Analysis:}

Statistical were carried out according $S A S$ (1987), and the kinetic parameters were calculated according to Baggot (1977). 


\section{RESULTES}

Norfloxacin and ciprofloxacin were rapidly absorbed after oral administration and appear in serum reaching to maximum serum concentrations after 2 and $0.67 \mathrm{~h}$ respectively (table 1-2 and fig. 1).

On the other hand, their levels in poultry tissues (muscle, liver and kidney) were decreased blow permissible MRL (maximum residue limits) at 7 and 5 days respectively (Table 3-4).

Table (1): Serum concentrations $(\mu \mathrm{g} / \mathrm{ml})$ after a single oral administration of norfloxacin (10mg/kg b.w.) or ciprofloxacin $(5 \mathrm{mg} / \mathrm{kg} \mathrm{b.w.)} \mathrm{for}$ broiler chickens.

\begin{tabular}{|c|c|c|}
\hline Time of sampling & $\begin{array}{c}\text { Norfloxacin }(n=5) \\
\text { mean } \pm \text { SD }\end{array}$ & $\begin{array}{c}\text { Ciprofloxacin }(n=5) \\
\text { mean } \pm \text { SD }\end{array}$ \\
\hline Pre-dose & 0.00 & 0.00 \\
\hline $10 \mathrm{~min}$ & $0.08 \pm 0.045$ & $3.6 \pm 0.42$ \\
\hline $20 \mathrm{~min}$ & $0.37 \pm 0.035$ & $4.00 \pm 0.48$ \\
\hline $30 \mathrm{~min}$ & $0.65 \pm 0.073$ & $4.42 \pm 0.031$ \\
\hline $40 \mathrm{~min}$ & $0.94 \pm 0.042$ & $4.46 \pm 0.045$ \\
\hline $1 \mathrm{~h}$ & $1.30 \pm 0.08$ & $4.40 \pm 0.091$ \\
\hline $2 \mathrm{~h}$ & $1.39 \pm 0.087$ & $4.20 \pm 0.076$ \\
\hline $3 \mathrm{~h}$ & $1.18 \pm 0.055$ & $3.83 \pm 0.082$ \\
\hline $4 \mathrm{~h}$ & $1.06 \pm 0.059$ & $3.50 \pm 0.22$ \\
\hline $6 \mathrm{~h}$ & $0.70 \pm 0.061$ & $3.00 \pm 0.045$ \\
\hline $8 \mathrm{~h}$ & $0.37 \pm 0.051$ & $2.30 \pm 0.076$ \\
\hline $12 \mathrm{~h}$ & $0.19 \pm 0.071$ & $2.12 \pm 0.051$ \\
\hline $24 \mathrm{~h}$ & $0.07 \pm 0.035$ & $1.80 \pm 0.042$ \\
\hline
\end{tabular}

Kafrelsheikh Vet. Med. J. Vol. 8 No. 1 (2010) 
Table (2): Pharmacokinetic parameters that describe the disposition of norfloxacin and ciprofloxacin after a single oral administration for broiler chickens (10mg and $5 \mathrm{mg} / \mathrm{kg}$ b.w.) respectively.

\begin{tabular}{|c||c||c||}
\hline pharmacokinetic parameters & $\begin{array}{c}\text { Norfloxacin }(\mathbf{n}=\mathbf{5}) \\
\text { mean } \pm \text { SD }\end{array}$ & $\begin{array}{c}\text { Ciprofloxacin (n =5) } \\
\text { mean } \pm \text { SD }\end{array}$ \\
\hline \hline $\mathrm{C}_{\max } \mu \mathrm{g} / \mathrm{ml}$ & $1.39 \pm 0.035$ & $4.46 \pm 0.109$ \\
\hline $\mathrm{t}_{\max } \mathrm{h}$ & $2.00 \pm 0.076$ & $0.67 \pm 0.051$ \\
\hline $\mathrm{t}_{1 / 2 \mathrm{el}} \mathrm{h}$ & $10.99 \pm 4.43$ & $8.85 \pm 0.234$ \\
\hline $\mathrm{AUC} \mu \mathrm{g} / \mathrm{ml} . \mathrm{h}$ & $10.09 \pm 0.902$ & $55.51 \pm 2.09$ \\
\hline $\mathrm{C}_{\max } / \mathrm{MIC}$ & $5.56 \pm 0.102$ & $4.46 \pm 0.074$ \\
\hline $\mathrm{AUC} / \mathrm{MIC}$ & $40.36 \pm 2.14$ & $55.51 \pm 2.09$ \\
\hline
\end{tabular}

Table (3): Norfloxacin residues $(\mu \mathrm{g} / \mathrm{gm})$ in poultry tissues after a single oral administration (10mg/kg b.w.) for broiler chickens.

\begin{tabular}{||c||c||c||c||}
\hline \multicolumn{1}{|c||}{\begin{tabular}{c|c||} 
Time \\
(day)
\end{tabular}} & $\begin{array}{c}\text { Muscle (n =5) } \\
\text { mean } \pm \text { SD }\end{array}$ & Kiver (n =5) \\
mean \pm SD & mean \pm SD \\
\hline \hline 5 & $31.2 \pm 2.84$ & $47.1 \pm 2.93$ & $28.1 \pm 2.55$ \\
\hline 6 & $14.8 \pm 0.676$ & $21.9 \pm 3.52$ & $13.3 \pm 3.54$ \\
\hline 7 & $1.61 \pm 0.106$ & $3.51 \pm 1.02$ & $1.86 \pm 0.57$ \\
\hline 8 & ND & $0.08 \pm 0.043$ & ND \\
\hline
\end{tabular}

Table (4): Ciprofloxacin residues $(\mu \mathrm{g} / \mathrm{gm})$ in poultry tissues after a single oral administration $(5 \mathrm{mg} / \mathrm{kg}$ b.w.) for broiler chickens.

\begin{tabular}{||c||c||c||c||}
\hline \multicolumn{1}{|c||}{\begin{tabular}{c|c||} 
Time \\
(day)
\end{tabular}} & $\begin{array}{c}\text { Muscle }(\mathbf{n}=\mathbf{5}) \\
\text { mean } \pm \text { SD }\end{array}$ & mean \pm SD & mean \pm SD \\
\hline \hline 4 & $27.6 \pm 4.14$ & $42 \pm 2.99$ & $36.3 \pm 3.52$ \\
\hline 5 & $11.5 \pm 1.58$ & $28.3 \pm 2.23$ & $14.1 \pm 1.59$ \\
\hline 6 & $0.06 \pm 0.042$ & $0.18 \pm 0.051$ & $0.085 \pm 0.016$ \\
\hline 7 & $\mathrm{ND}$ & $0.06 \pm 0.016$ & $\mathrm{ND}$ \\
\hline
\end{tabular}

Kafrelsheikh Vet. Med. J. Vol. 8 No. 1 (2010) 


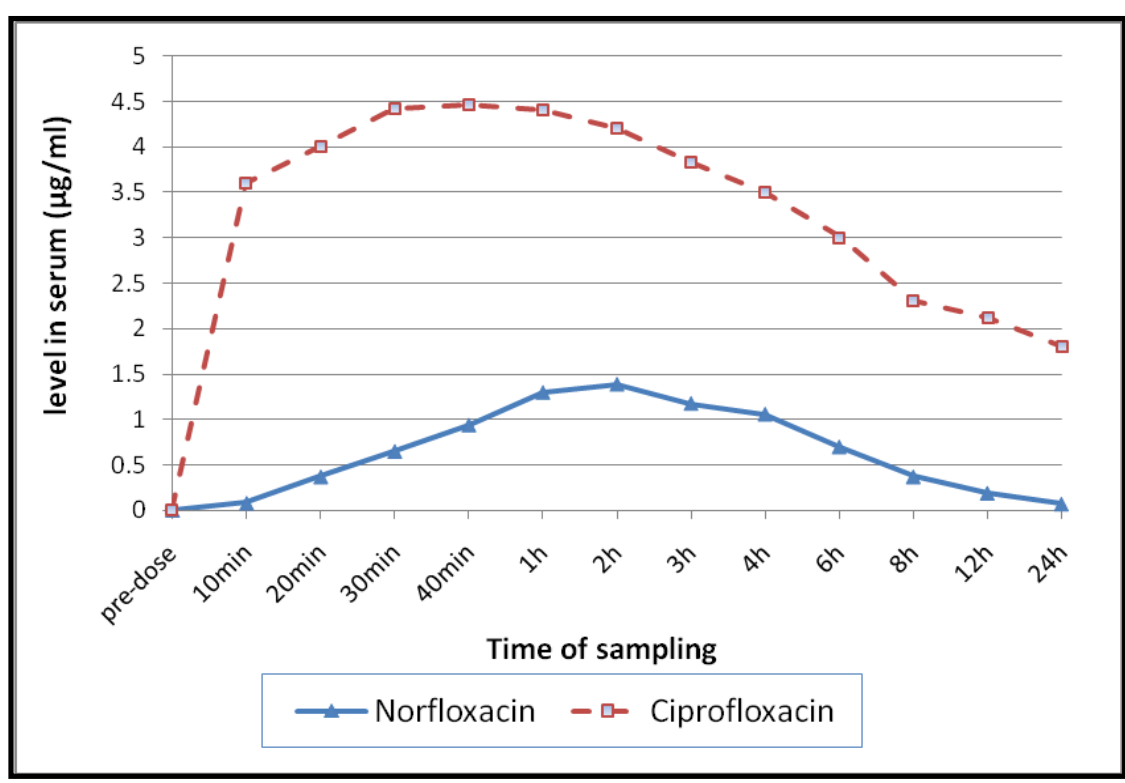

Fig. (1): Serum concentrations $(\mu \mathrm{g} / \mathrm{ml})$ after a single oral administration of norfloxacin (10mg/kg b.w.) or ciprofloxacin $(5 \mathrm{mg} / \mathrm{kg}$ b.w.) for broiler chickens.

\section{DISCUSSION}

Quinolones are characterized by common pharmacokinetic properties as its rapid oral absorption, attainable serum and tissue concentration above the MIC for most of Gram-negative and many Gram-positive organisms, and relatively long half-lives in plasma that allowing dose intervals of at least 12h (Anadón et al, 1990). So the authors concluded that these features suggest possible clinical applications of these antimicrobials.

In this study $\mathrm{C}_{\max }$ of norfloxacin after its single oral administration was $1.39 \mu \mathrm{g} / \mathrm{ml}$ and $t_{\max }$ was $2 \mathrm{~h}$, whereas these values were $4.46 \mu \mathrm{g} / \mathrm{ml}$ and $0.67 \mathrm{~h}$ with ciprofloxacin respectively. This results indicate that 
ciprofloxacin is rapidly absorbed in chickens than norfloxacin, although norfloxacin dose was double ciprofloxacin dose, but the elimination halflife was higher with norfloxacin than with ciprofloxacin $(10.99 \mathrm{~h}$ and $8.85 \mathrm{~h}$ respectively) indicating slow final disappearance of the norfloxacin from blood than ciprofloxacin.

Nearly similar results were previously reported by Laczay et al (1998) when administered a single oral dose of norfloxacin for chickens $\left(10 \mathrm{mg} / \mathrm{kg}\right.$ b.w) and recorded $\mathrm{C}_{\max } 1.46 \mu \mathrm{g} / \mathrm{ml}$ and $\mathrm{t}_{\max } 1.99 \mathrm{~h}$. They mentioned that Anadón et al (1992) found higher peak concentration $\left(\mathrm{C}_{\max } 2.89 \mu \mathrm{g} / \mathrm{ml}\right)$ and much faster absorption $\left(\mathrm{t}_{\max } 0.22 \mathrm{~h}\right)$ of norfloxacin after a single oral dose of $8 \mathrm{mg} / \mathrm{kg}$ in chickens. The authors commented that the reason for these differences is not clear and several factors might be involved. In the referred study the sodium salt of norfloxacin was administered and we used a commercial product containing the norfloxacin base. On the other hand similar values of this study were recorded by Atta and Sharif (1997) when administered a single oral dose of ciprofloxacin for chickens $\left(5 \mathrm{mg} / \mathrm{kg}\right.$ b.w) and found $\mathrm{C}_{\max }$ $4.67 \mu \mathrm{g} / \mathrm{ml}$ and $t_{\max } 0.71 \mathrm{~h}$. In contrast we found El-Gendi et al (2001) recorded less levels $\left(\mathrm{C}_{\max } 1.24 \mu \mathrm{g} / \mathrm{ml}\right)$ and long time $\left(\mathrm{t}_{\max } 1.27 \mathrm{~h}\right)$ although they give ciprofloxacin double dose of this study (a single dose of $10 \mathrm{mg} / \mathrm{kg}$ b.w.) orally for broiler chickens.

The previously recorded $\mathrm{MIC}_{90}$ for norfloxacin against major poultry pathogenic Gram-negative bacteria (E.coli, Salmonella sp., Pasteurella spp) and mycoplasma were $0.25 \mu \mathrm{g} / \mathrm{ml}$ (Hannan et al., 1989 and Prescott and Baggot,1993).Comparing with this results, norfloxacin level; in this study, was still above or equal to $\mathrm{MIC}_{90}$ of major poultry pathogenic Gram-negative bacteria and mycoplasma between 0.33-10 h Kafrelsheikh Vet. Med. J. Vol. 8 No. 1 (2010) 
after administration of the drug. Closely similar results were previously recorded by Hannan et al., (1989) and Prescott and Baggot (1993) where they told that after pulse dosing of norfloxacin $(15 \mathrm{mg} / \mathrm{kg})$ the plasma concentrations increased rapidly and significantly exceeded the $\operatorname{MIC}_{90}(0.25 \mu \mathrm{g} / \mathrm{ml})$ against the major poultry pathogen Gram-negative bacteria and mycoplasmas by $0.5 \mathrm{~h}$ in chickens and remained above for $10 \mathrm{~h}$. Otherwise, the previously reported $\mathrm{MIC}_{90}$ for ciprofloxacin against most Gram-negative and Gram-positive bacteria affecting poultry were $<1 \mu \mathrm{g} / \mathrm{ml}$ (Presccott and Yielding, 1990). Ciprofloxacin levels were maintained above $\mathrm{MIC}_{90}$ of major poultry pathogenic bacteria more than 24h. Similar results were previously mentioned by Presccott and Yielding, (1990) Atta and Sharif, (1997) when they found that ciprofloxacin concentration in plasma of chickens were still $24 \mathrm{~h}$ much higher than its MIC against most Gram-negative and Gram-positive bacteria affecting poultry after oral administration of $(5 \mathrm{mg} / \mathrm{kg})$ as a single dose.

The main pharmacokinetic/pharmacodynamic (PK/PD) parameters correlating with efficacy, minimizing the risk of development of resistance and the best surrogate of drug activity are the $\mathrm{C}_{\max } / \mathrm{MIC}$ and AUC/MIC ratios (Toutain et al, 2002) specially if its endpoints are equal to or higher than 10 and 125 h respectively (Hyatt et al, 1995; Schentag, 1999; Pickerill et al, 2000 and Schentag et al, 2001). In this study $\mathrm{C}_{\max }$ /MIC and AUC/MIC for norfloxacin were 5.56 and 40.36h whereas this ratios were 4.46 and $55.51 \mathrm{~h}$ respectively for ciprofloxacin. In other study as Drusano et al., (1993) determined a more higher ratio for $\mathrm{C}_{\max } / \mathrm{MIC}$ (greater than 10-20:1) when they administered of norfloxacin once daily in an animal infection. Although these values not reached 
these presumed endpoints for two drugs, their activity may be expected because the activity of fluoroquinolones against Gram-negative and Gram-positive strains is rather time dependent (Schneider et al, 2004).

The ever increasing use of quinolones, fluoroquinolones in poultry industry will cause their residual deposition in the poultry products resulting in the drug resistant bacteria and other harmful effects of drug residues on consumer, (i-e) the safe food is free of residues, that meaning the levels of residues in tissues is lower than MRL according to the regulation (Amjad et al, 2005). In this respect the US FAA has set a tolerance level of $0.3 \mu \mathrm{g} / \mathrm{gm}$ for fluoroquinolone in poultry tissues in USA (Schneider and Donoghue, 2004). Choi et al, (2006) when analyzed fluoroquinolone residues in edible chicken tissues ;in republic of Korea, with limits of quantitation $0.0125 \mathrm{ug} / \mathrm{gm}$ for norfloxacin and ciprofloxacin reported that this limit were lower than the MRL authorized by the European Community. While Sijun et al, (2007) in republic of China, when determined a trace level of 10 quinolones in chicken tissues including norfloxacin and ciprofloxacin mentioned that the MRL for quinolones in different muscle tissues established in many countries are $0.01 \mu \mathrm{g} / \mathrm{gm}$. According of these MRLs for norfloxacin and ciprofloxacin in poultry tissues, the present study illustrated that residues of this drugs were decreased than these levels in chicken tissues (muscle, liver and kidney) at 7 and 5 days respectively, considering these times are enough as withdrawal periods. Herein we must record the clear observation that the concentrations of two drugs were somewhat still higher in liver as compared to those in kidney and muscle which may attributed to higher rates of their excretion from the kidney specially ciprofloxacin ; as compared to other quinolone, due to its lower 
lipophylicity (Aries et al, 1976 and Amjad et al, 2005). And previously Aries et al, (1976) added that to decrease kidney, liver and muscle residues the washing out time periods should be increased along with intake of vitamin $\mathrm{C}$ which will render the kidney to work in more acidic medium thus increase the secretion of these drugs.

Nearly similar results were reported by Zblinsk et al, (1999) when found residual traces of norfloxacin in poultry tissues from 6-12 days after dosing in drinking water $(175 \mathrm{mg} / \mathrm{l}$ of active substance) for 5 consecutive days while Anadon, et al (1992) recorded more long time for norfloxacin residues in fat, kidneys and liver $(0.05 \mu \mathrm{g} / \mathrm{gm}$ on day 12$)$ after the end of its dosing $8 \mathrm{mg} / \mathrm{kg}$ b.w. orally on 4 successive days. On contrast we found Shen et al, (2004) recorded more less time for norfloxacin residues in chicken muscles where they mentioned that the concentrations of norfloxacin decreased gradually with time in the chicken muscles after oral treatment, giving a concentration less than $0.005 \mathrm{ug} / \mathrm{ml}$ in fifth day. Otherwise, similar results on ciprofloxacin residues were recorded by ElGendi et al, (2001) when give it as a single dose of $10 \mathrm{mg} / \mathrm{kg}$ b.w. orally for broiler chickens and found drug residues was completely disappeared from all tissues (liver, kidneys, spleen and lungs) after 5 days from stopping of the drug medication. And by Anadòn et al, (2001) when administered ciprofloxacin $8 \mathrm{mg} / \mathrm{kg}$ b.w. for broiler chickens for 3 successive days and found the mean tissue concentrations (ranged between 0.011 to $0.075 \mu \mathrm{g} / \mathrm{gm}$ ) persisted for 5 days, although nearly the same authors (Anadòn et al, 1995) previously recorded more long time for ciprofloxacin residues in chicken's muscle, liver and kidney ranged between 0.02 to $0.075 \mu \mathrm{g} / \mathrm{gm}$ and persisted on day 12 after dosing. In keeping with these results Garcia Ovando et al., 
(1999) mentioned that ciprofloxacin remains in the body for less time than the other quinolone and this characteristic of ciprofloxacin suggests the advantage of a shorter withdrawal time for food producing animals treated with this antimicrobial. Moreover, they added ciprofloxacin is a good present or future alternative for use in food producing animals as it has shown quick elimination from chicken bodies with minor possibilities of leaving residues in treated animals

Finally it could be concluded that, on the basis of plasma concentration and reported MIC for avian pathogenic microorganisms, the administration of norfloxacin $(10 \mathrm{mg} / \mathrm{kg})$ or ciprofloxacin $(5 \mathrm{mg} / \mathrm{kg})$ orally are adequate at $24 \mathrm{~h}$ intervals for control of avian bacterial diseases. Furthermore the relatively high $\mathrm{C}_{\max } / \mathrm{MIC}$ ratio and the long elimination half-life of norfloxacin can allow a once-per-day pulse-dose schedule in drinking water. Taking into account withdrawal periods of 7 and5days allowed times for norfloxacin and ciprofloxacin concentrations (respectively) in meat, liver and kidney are adequate to decrease to an acceptable levels (blow MRL authorized for these to drugs) prior to slaughter.

\section{REFERENCES}

- Amjad, H.; Iqbal, J. and Naeem, M. (2005): Analysis of some residual antibiotics in muscle, kidney and liver samples of broiler chicken by various methods. Proc. Pakistan Acad. Sci. 42 (4): 223 231.

- Anadòn, A.; Martinez,-Larranaga, M. R.; Diaz, M. J.; Bringas P.; Martìnez, M. A.; Fernández-Cruz, M. L.; Fernández, M. C. and Fernández, $\boldsymbol{R}$. (1995): Pharmacokinetics and residues of enrofloxacin in chickens. Am J Vet Res, (56): 501-505. 
- Anadòn, A.; Martinez,-Larranaga, M. R.; Diaz, M. J.; Veiez, C. and Bringas P. (1990): Pharmacokinetics and residue studies of quinolone compounds and olaquindox in poultry. Am. Res. Vet, 21(suppl1): 137s-144s.

- Anadòn, A.; Martinez,-Larranaga, M. R.; Iturbe, J.; Martìnez, M. A.; Diaz, M.; Frejo, T. and Martinez, M. (2001): Pharmacokinetics and residues of ciprofloxacin and its metabolites in broiler chickens. Res. Vet. Sci., 71(2): 101-109.

- Anadòn, A.; Martinez,-Larranaga, M. R.; Velez, C.; Diaz, M. J. and Bringas $P$. (1992): Pharmacokinetics of norfloxacin and its Ndesethyl- and oxo-metabolites in broiler chickens. Am J Vet Res, 53(11): 2084-2089.

- Ariens, E. J; Simonis, A. M. and Offermerier, J. (1976): The toxicological action. In Introduction to general Toxicology. $2^{\text {nd }}$ ed., 13-78. Academic Press. New York, San Francisco and Landon.

- Atta, A. H. and Sharif, L. (1997): Pharmacokinetics of ciprofloxacin following intravenous and oral administration in broiler chickens. J. Vet. Pharmacol. Therap. 20(4): 326-329.

- Baggot, J. D. (1977): Principles of Drug Diposition in Domestic Animals: The Basis of Veterinary Clinical Pharmacology. WB Saunders, Philadelphia 144-189.

- Campoli-Richards, D. M.; Monk, J. P.; Benfield, P.; Todd, P. A. and Ward, A. (1988): Ciprofloxacin, A review of its antibacterial activity, pharmacokinetic properties and therapeutic use. Drugs, 35, 373-447. 
- Choi, J. H.; Abd El-Aty, A. M.; Shen, J. Y.; Kim, M. R. and Shim, J. $\boldsymbol{H}$. (2006): Analysis of fluoroquinolones residues in edible residues using supercritical fluid extraction. Berl Munch Tieraztl Wochenschr, 119(11-12): 456-460.

- Crumplin, G. C.; Kenwright, M. and Hurst, T. (1984): Investigations into the mechanism of action of the antibacterial agent norfloxacin. $\mathbf{J}$ antimicrob. Chemother. 13(suppl. B): 9-23.

- Demoleas,S.E.and Davies, G. F. (1988): Quinolones: oral antibiotics of the future. J. Am. Paediatric Vet. Med. Assoc. 78, 522-525.

- Drusano, G. L.; Johnson, D. E.; Rosen, M. and Standiford, H. C. (1993): Pharmacokinetics of fluoroquinolone antimicrobial agent in a neutropenic rat modle of Pseudomonas sepsis. Antimicrob. Agents Chemother (37): 483-490.

- El-Gendi, A. Y.; El-Banna, H. A.; Abo Norag, M. and Gaber, M. (2001): Disposition kinetics of danofloxacin and ciprofloxacin in broiler chickens. Dtsch Tieraztl Wochenschr, 108(10): 429-434.

- Garcia Ovando, H.; Gorla, N.; Luders, C.; Poloni, G.; Errecalde, C.; Prieto, G. and puelles, I. (1999): Comparative pharmacokinetics of enrofloxacin and ciprofloxacin in chickens. J. Vet. Pharmacol. Therap. (22): 209-212.

- Hackbarth, C. J.; Chamers, H. F.; Stella, F.; Shibl, A. M. and Sande, M. A. (1986): Ciprofloxacin in experimental Pseudomonas aeroginosa meningitis in rabbits. J. Antimicrob. Chemother. 18(Suppl. D): 65-69. 
- Hannan, P. C. T.; O'Hanlon, P. J. and Rogers, N. H. (1989): In vitro evaluation of various quinolone antibacterial agents against veterinary mycoplasmas and porcine respiratory bacterial pathogens. Res. Vet. Sci. (46): 202-211.

- Horie, M., Saito, K., Nose, N. and Nakazawa, H. (1994): Simultaneous determination of benofloxacin, danofloxacin, enrofloxacin and ofloxacin in chicken tissues by high-performance liquid chromatography. J of Chromatography B, 653: 69-76.

- Hyatt, J. M.; McKinnon, P. S.; Zimmer, G. S. and Schentag. J. J. (1995): The importance of pharmacokinetic / pharmacodynamic surrogate markers to outcome. Clin. Pharmacokinetics (28): 143-160.

- Ito, A, Hirai, K., Inoue, M., Koga, H., Suzue, S., Irikura, T. and Mitsuhashi, S. (1980): In vitro antibacterial activity of AM-715, a new nalidixic acid analog. Antimicrob. Agents Chemother. 17(2): 103-108.

- Keck, G. and Borne, P. M. (1995): Antimicrobial chemotherapy; new considerations and their applications to veterinary medicine. Revue De Medicine Veterinari Toulouse, 146: 309-320.

- Laczay, P.; Semjèn, G.; Nagy, G. and Lehel, J. (1998): Comparative studies on the pharmacokinetics of norfloxacin in chickens, turkeys and geese after a single oral administration. J. Vet. Pharmacol. Therap. (21): 161-164.

- Lefevre, J. C.; Tempesta, M. C.; Gaubert, E. and Lareng. M. B. (1988): In vitro activity of six quinolone derivatives against Neisseria gonorrhoeae. Chemotherapy, 34, 315-317. 
- Neer,T.M.(1988):Clinical pharmacologic features of fluoroquinolone antimicrobial drugs. J. Am. Vet. Med. Assoc. 193: 577-580.

- Neu, H. C. and Labthavikul, P. (1982): In vitro activity of norfloxacin, quinolinecarboxilic acid, compared with that of B-lactam, aminoglycosides, and trimethoprim. Antimicrob. Agents and Chemother. 22, 23-27.

- Neu, H. C.; Kumada, T.; Chin, N. X. and Mandell, W. (1987): the post-antimicrobial suppressive effect of fluoroquinolone agents. Drug Experimental Clinical Research XIII, 63-67.

- Norrby, S. R. and Jonsson, M. (1983): Antibacterial activity of norfloxacin. Antimicrob. Agents and Chemother. 23, 15-18.

- Papich, M. G. (1998): Antibacterial drug therapy, Focus on new drugs. Vet. Clin. N. A.; Small Animal Prscyice. (28): 215-231.

- Pickerill, K. E.; Paladino, J. A. and Schentag. J. J. (2000): Comparison of the fluoroquinolones based on pharmacokinetic and pharmacodynamic parameters. Pharmacotherapy (20): 417-428.

- Prescott, J. F. and Baggot, J. D. (1993): The fluoroquinolones. In antimicrobial therapy in veterinary medicine. Eds Prescott, J. F. and Baggot, J. D. pp 252-262, $2^{\text {nd }}$ ed. Iowa. State University Press. Ames.

- Prescott, J. F. and Yielding K. M. (1990): In vitro susceptibility of selected veterinary bacterial pathogens to ciprofloxacin, enrofloxacin and norfloxacin. Canadian J Vet. Res., 54, 195-197.

- Proctor, R. W., Craig, W. and Kunin, C. (1978): Cetocycline, tetracycline analog: In vitro studies of antimicrobial activity, serum binding, lipid solubility, and uptake by bacteria. Antimicrob. Agents Chemother. 13(4): 598-604. 
- Ryoji, Y.; Masaki, K.; Takashi, O.; Fumiki, M. and Masahiko, K. (2006): Simultaneous determination of residual veterinary drugs in bovine, porcine and chicken muscle using liquid chromatography coupled with electrospray ionization tandem mass spectrometry. Biosci. Biotechnol. Biochem., 70 (1): 54-65.

- Sárközy, G.; Semjèn, G. and Laczay, P. (2004): Disposition of norfloxacin in broilers and turkeys after different methods of oral administration. Vet. J 168 (3): 312-316.

- Schentag, J. J. (1999): Antimicrobial action and pharmackinetics/ pharmacodynamics: The use of AUIC to improve efficacy and avoid resistance. J. Chemother. (11): 426-439.

- Schentag, J. J.; Gilliland, K. K. and Paladino. J. A. (2001): What have we learned from pharmacokinetic and pharmacodynamic theories. Clin. Infect. Dis. 32:S39-S46

- Schneider, M. J. and Donoghue, D. J. (2004): Comparison of bioassay and liquid chromatography- fluorescence-mass spectrometry method for the detection of incurred enrofloxacin residues in chicken tissues. Poultry Science, (83): 830-834.

- Schneider, M.; Vallé, M.; Woehrlé, F. and Boisramé, B. (2004): Pharmacokinetics of marbofloxacin in lactating cows after repeated intramuscular administrations and pharmacodynamics against mastitis isolated strains. J. Dairy Sci. (87): 202-211.

- Shah, P. M. (1990): Antimicrobial properties of quinolones. Eur. J. Pharmacol. 183(1): 67-69. 
- Shen, J. Y.; Kim, M. R.; Lee, C. J.; Kim, I. S.; Lee, K. B. and Shim, J. H. (2004): Supercritical fluid extraction of the fluoroquinolones norfloxacin and ofloxacin from orally treated-chicken breast muscles. Analytica Chimica Acta, 513(2): 451-455.

- Sijun, Z.; Haiyang, J.; Xueliian, L. I.; Tiejun, M. I.; Cun, L.I. and Jianzhong, S. (2007): Simultaneous determination of trace levels of 10 quinolones in swine, chicken and shrimp muscle tissues using HPLC with programmable fluorescence detection. J. Agric. Food Chem., 55(10): 3829-3834.

- Statistical Analysis System, (1987): SAS User's Guide: Statistical Methods. SAS Institute, Inc., Cary, North Carolina.

- Toutain, P.L.; Del Castillo, J. R. E. and Bousquet-Melou, A. (2002): The pharmacokinetic-pharmacodynamic approach to rational dosage regimen for antibiotics. Res. Vet.Sci., (73): 105-114.

- Zblinsk, R.; Cezary, K. and Elzbieta, K. (1999): Distribution and depletion of norfloxacin from chicken tissues and eggs. Medwet. Lubin. 55(12): 818-822. 
در اسات مقارنة بين بقايا النور فلوكساسين و السبروفلوكساسين في دجاج التسمين مع إثارة خاصة لفترة الانسحاب

وجيه مصطفي عبل السلام الثيخ - منى عباللطيف أحد الكحي

قسم الفارماكولوجيا - معهد بحوث صحة الحيوان (المعمل الفرعي بطنطا)

ثم إعطاء جرعة واحدة عن طريق الفم من النورفلوكساسين (10 ملجم/كجم من وزن الطائر) والسبروفلوكساسين (5 ملجم/كجم من وزن الطائر) لعدد 30 من دجاج التسمين ، وتم جمع عينات من سيرم الدم لقياس مستوى الدوائين ، ومن أنسجة الدجاج (العضلات - الكبد - الكلى) لتتبع البقايا الدوائية لكلا العقارين باستخدام جهاز الضغط العالي السائل مع الكاشف الفلوروسيني • أظهرت الدراسة وصول الدوائين بمستويات عالية لسيرم الدم حيث وصلا لأعلى تركيز (1,39 و 4,46 ميكروجرام/مل) بعد 2 و 0,67 ساعة ، مع استمرار مستوى الدوائين في الدم بنسبة أعلى من أقل تركيز مثبط لنمو معظم الميكروبات السالبة والموجبة المسببة للأمراض في الدواجن لمدة 10 و 24 ساعة لكل من النورفلوكساسين والسبروفلوكساسين على التوالي. كما تبين من خلال هذه الدراسة أن إعطاء هذين الدوائين بهذه الجرعة كل 24 ساعة كافي للسيطرة على الأمراض التي تسببها الميكروبات الحساسة لهما وأن 7 و 5 أيام تعتبر مدة كافية لانخفاض مستوي الدوائين في أنسجة الدجاج (العضلات - الكبد - الكلى) لمستوى أقل من الحدود المسوح بها دولياً لكل من النورفلوكساسين والسبروفلوكساسين على التوالي. 